\title{
SOCIAL STUDIES (PIPS) SEBAGAI UPAYA MENINGKATKAN SOCIAL RESPONSIBILITY DAN SOCIAL SKILLS PESERTA DIDIK DI TENGAH GLOBALISASI
}

\author{
Rahman Abidin \\ Universitas Sebelas Maret \\ rahmanweew@gmail.com
}

\begin{abstract}
ABSTRAK
Secara kelembagaan, kurikulum Pendidikan IPS harus disesuaikan dengan tantangan global, intensitas forum akademik ditingkatkan kuantitas dan kualitasnya. Pada level kelas, pengajar perlu meningkatkan kapasitasnya melalui pelatihan dan kreatif dalam melaksanakan pembelajaran yang bermakna sebagai upaya menghasilkan good citizen dapat terwujud. Pada era globaliasi banyak efek yang meresap dalam saraf kehidupan. Efek tersebut menimbulkan masalah sosial seperti individualistis, egoistis, kurang dapat berkomunikasi secara efektif, rendahnya empati, kurangnya rasa tanggung jawab, tingkat disiplin rendah, kurang bekerjasama dan berinteraksi didalam kehidupan bermasyarakat. Pendidikan IPS mempunyai peranan yang sangat penting dalam meningkatkan tanggung jawab sosial dan keterampilan sosial peserta didik, dengan begitu peserta didik diharapkan dapat hidup secara lebih fungsional dan bermakna di era globalisasi.
\end{abstract}

Kata Kunci : Social Studies, Pisocial Responsibility dan Skills, Globalisasi

\section{PENDAHULUAN}

Arus global membawa pengaruh yang sudah merasuki berbagai sendi kehidupan, termasuk kehidupan peserta didik baik di keluarga, sekolah, dan masyarakat. Selain membawa dampak positif, tidak sedikit pengaruh negatif arus globalisasi tersebut, termasuk didalamnya masalah sosial yang saat ini menjadi permasalahan bangsa yang cukup memprihatinkan. Masalah sosial sudah tampak dalam kehidupan seharihari peserta didik, seperti sikap individualistis, egoistis, kurang dapat berkomunikasi secara efektif, rendahnya rasa empati, kurang rasa tanggung jawab, tingkat disiplin rendah, kurang bekerja sama dan berinteraksi didalam kehidupan bermasyarakat, atau dikenal dengan istilah social autism atau social insulation. Pendidikan bukan hanya menciptakan seseorang yang ahli dalam bidang tertentu, namun harus mampu membawa diri dalam lingkungan bermasyarakat, berbangsa dan bernegara sesuai dengan norma dan aturan yang berlaku. Pendidikan IPS berkepentingan menjaga semangat berwarganegara yang baik, sehingga harus mampu mensikapi era global 
Social Studies (PIPS) Sebagai Upaya Meningkatkan Social Responsibility dan Social Skills Peserta Didik dI Tengah Globalisasi.

(Rahman Abidin)

tersebut dengan baik melalui pembelajaran yang lebih bermakna agar mampu meredam dampak negatif perkembangan global. Sebagai warga negara, perwujudan individu yang berkualitas atau warga negara yang baik sangat dibutuhkan oleh negara dalam rangka proses pembangunan sedangkan pengaruh globalisasi ternyata mampu memaksa sebagian generasi muda meninggalkan nilai-nilai kebaikan, sehingga mereka terjebak dengan kebiasaan yang jauh dari nilai-nilai kebaikan tersebut. Dunia pendidikan mempunyai peranan yang sangat mendasar dalam membentuk karakter bangsa lembaga pendidikan tidka hanya berkewajiban meningkatkan mutu akademis, tetapi juga bertanggung jawab dalam membentuk karakter bangsa. Mutu akadmis dan pembentukan karakter yang baik merupakan dua hal yang harus dikombinasikan sebagai solusi tangangan dalam masa globalisasi (Andriyanto dan Muslikh, 2018 : vii).

Maksut beberapa fenomena sosial yang kurang relevan dilakukan oleh siswa akhir-akhir ini, seperti: tindak kriminal, kekerasan, pelecehan seksual, tawuran antar pelajar, destruksi tanggung jawab sosial, dan sebagainya. Meskipun tidak mencerminkan siswa pada umumnya, namun terjadi berulang kali sampai sekarang, sehingga patut menjadi perhatian bebagai pihak; pemerintah, kalangan pendidikan, keluarga, dan masyarakat. Pendidikan di sekolah mendapat kritik terkait kurangnya pembangunan aspek afektif di banding kognitif. Ketidak seimbangan ini diindikasikan sebagai salah satu fenomena kekerasa di atasyang tercetak generasi yang pintar, tetapi tidak memiliki karakter yang dibutuhkan bangsa. Disisi lain pada saat yang sama masyarakat mempertontonkan benturan-benturan asosial, seperti: konflik, kekerasan, kenakalan remaja, pelecehan seksual, terorisme dan lain sebagainya. Modal sosial bangsa Indonesia yang penuh dengan nilai-nilai kearifan seolah tidak mendapat tempat, sampai melahirkan keprihatinan, solidaritas, keadilan, persatuan, dan nilai-nilai lainnya yang bersumber dari sosio budaya bangsa (nilai-nilai luhur). Berbagai perilaku sosial di sekolah dan masyarakat tersebut masih terjadi secara sporadis dan diperlihatkan oleh berbagai media, keadaan ini tentu beresonansi dengan berbagai pihak termasuk siswa lain yang sedang dalam masa pembangungan karakter.

Akibatnya secara perlahan siswa mengalami pergeseran tata krama kehidupan sosial dan etika moral dalam praktik kehidupan sekolah. Pergeseran ini nampak terjadi di berbagai sekolah di Indonesia (UNICEF, 2014). Pendidikan merupakan salah satu yang bertanggung jawab besar dalam melahirkan warga negara Indonesia yang memiliki 
karakter kuat sebagai modal dalam membangun peradaban tinggi dan unggul. Karakter bangsa yang kuat merupakan produk dari pendidikan. Karena itu, IPS dapat dikatakan sebagai studi mengenai perpaduan antara ilmu-ilmu dalam rumpun ilmu-ilmu sosial dan juga humaniora untuk melahirkan pelakupelaku sosial yang dapat berpartisipasi dalam memecahkan masalah-masalah sosio kebangsaan. Bahan kajiannya menyangkut peristiwa, seperangkat fakta, konsep dan generalisasi yang berkait dengan isu-isu aktual, gejala dan Peran Guru IPS sebagai Pendidik dan Pengajar dalam masalah-masalah atau realitas sosial serta potensi daerah.

Pada era globalisasi seperti sekarang ini, setiap warga Negara termasuk peserta didik dituntut untuk mempunyai sejumlah keterampilan yang diperlukan dalam kehidupan bukan hanya sebagai warga Negara, tetapi juga sebagai warga dunia sehingga kehidupan peserta didik dapat lebih fungsional dan lebih bermakna. Beberapa keterampilan yang diperlukan pada era globalisasi yaitu meliputi: 1) critical thinking and problem solving, 2) collaboration across network and leading by influence, 3) agility and adaptability, 4) initiative and entrepreneurialism, 5) effective oral and written communication, 6) accessing and analysing information, and 7) curiosity and imagination (Wagner, 2008). Soemantri (Syaodih 2012: 2) menilai bahwa "pembelajaran IPS sangat menjemukan karena penyajiannya masih bersifat monoton dan ekspositoris, sehingga peserta didik kurang antusias dan mengakibatkan pelajaran kurang menarik". Sedangkan Al-Muchtar (2007: 131) mengemukakan hasil dari penelitian tentang pembelajaran IPS bahwa "dalam pembelajaran IPS orientasi guru menjadi kuat terhadap proses pemberian materi pelajaran, sedangkan pengembangan kemampuan berpikir dan bersikap sebagai bekal menjadi warga Negara yang baik tidak banyak diperhatikan"

Somantri dalam Sapriya (2009 :11) bahwa: "Pendidikan IPS adalah seleksi dari disiplin ilmu-ilmu sosial dan humaniora, serta kegiatan dasar manusia yang diorganisasikan dan disajikan secara ilmiah dan psikologis untuk tujuan pendidikan" IPS masih bersifat elementer bersifat dasar dan fundamental belaka. Pada tingkat yang lebih tinggi ilmu ini sudah berkembang sedemikian rupa, karena itu IPS yang dipelajari pada perguruan tinggi disebut dengan istilah lain yaitu social science. Masih menurut Nursid (2008 :1-17), pendidikan IPS adalah suatu penyederhanaan disiplin ilmu-ilmu sosial, ideologi negara dan disiplin ilmu lainnya serta masalah-masalah sosial terkait 
Social Studies (PIPS) Sebagai Upaya Meningkatkan Social Responsibility dan Social Skills Peserta Didik dI Tengah Globalisasi.

(Rahman Abidin)

yang diorganisasikan dan disajikan secara ilmiah dan psikologis untuk tujuan pendidikan pada tingkat pendidikan dasar dan menengah. IPS dalam pendidikan merupakan suatu konsep yang mengembangkan pengetahuan, sikap, dan keterampilan sosial dalam rangka membentuk dan mengembangkan pribadi warga negara yang baik, juga telah menjadi bagian dari wacana kurikulum dan sistem pendidikan di Indonesia, dan merupakan program pendidikan sosial pada jalur pendidikan sekolah. Sebagaimana diungkapkan oleh Nursid (2008: 20) bahwa Mata pelajaran IPS bertujuan mengembangkan potensi peserta didik agar peka terhadap masalah sosial yang terjadi dimasyarakat, memiliki sikap mental positif terhadap perbaikan segala ketimpangan yang terjadi, dan terampil. Fraenkel (Sardjiyo 2007: 25) membagi tujuan IPS dalam empat kategori yaitu: 1) Pengetahuan 2) Keterampilan 3) Sikap 4) Nilai. Pengetahuan adalah kemahiran dan pemahaman terhadap sejumlah informasi dan ide-ide. Tujuan pengetahuan ini membantu siswa untuk belajar lebih banyak tentang dirinya, fisiknya dan dunia sosial. Mengatasi setiap masalah yang terjadi sehari-hari baik yang menimpa dirinya sendiri maupun yang menimpa kehidupan masyarakat.

Pendidikan IPS yang selama ini terkesan jalan di tempat, masih belum mendapatkan posisi yang membanggakan di tengah arus globalisasi. Menghadapi fenomena ini, pendidikan IPS idealnya harus responsif dan menata diri berhadapan dengan globalisasi. Dengan demikian perlu adanya penguatan peran IPS, sehingga pembelajaran IPS tidak hanya terfokus pada ranah kognitif saja, akan tetapi pembelajaran IPS juga dapat meningkatkan tanggung jawab sosial dan keterampilan sosial peserta didik, sehingga dapat mempersiapkan peserta didik untuk hidup secara lebih fungsional dan bermakna di era globalisasi. Pada artikel ini, Penulis bertujuan untuk membahas bagaimana social studies dapat meningkatkan meningkatkan social responsibility dan social skills peserta didik di tengah globalisasi

\section{PEMBAHASAN}

Tidak sedikit Social responsibility dan social skills yang harus dikuasai oleh setiap warga Negara termasuk peserta didik pada era globalisasi memberikan implikasi pada dunia pendidikan untuk dapat mempersiapkan peserta didik supaya dapat aktif berpartisipasi dalam masyarakat global. Meitri Group (2009), mengemukakan empat keterampilan utama pada era globalisasi sekarang ini yaitu meliputi literasi zaman 
digital, berpikir inventifmodal intelektual, komunikasi interaktif-keterampilan sosial dan personal, dan hasil-hasil berkualitas dan terkini. Dengan banyaknya keterampilan yang harus dikuasai, sekolah dituntut untuk mengubah proses pembelajaran sehingga peserta didik dapat menguasai sejumlah keterampilan yang diperlukan dalam kehidupan masyarakat global. Termasuk didalamnya proses pembelajaran IPS, dimana IPS punya peranan yang sangat penting dalam upaya meningkatkan keterampilan peserta didik

\section{Peran Social Studies Di Tengah Globalisasi}

Pendidikan IPS sebagai synthetic discipline berusaha mengorganisasikan dan mengembangkan substansi ilmu-ilmu sosial secara ilmiah dan psikologis untuk tujuan pendidikan. PIPS mempunyai peran penting dalam membangun identitas nasional untuk menjadikan siswa yang kreatif, mampu memecahkan masalah diri dan lingkungannya, serta menjadi warga negara yang baik dan bermoral. Di tengah iklim globalisasi, PIPS tetap diperlukan baik sebagai 14 penopang identitas nasional, maupun problem solver masalah-masalah lokal, regional, nasional, dan global. Berbagai masalah PIPS baik dari kurikulum, pengembangan di LPTK, kemampuan guru dalam mengajarkan, dan kebijakan pemerintah dalam mendorong PIPS yang ideal perlu terus diusahakan secara optimal.

Pendidikan IPS (Social Studies) menurut Mayhood dkk., (1991: 10), adalah "The Social Studies are comprissed of those aspests of 3 history, geography, and pilosophy which in practice are selected for instructional purposes in schools and collegs" National Council for the Social Studies (NCCS) memberikan definisi yang lebih tegas, seperti yang dikutip Catur (2004), bahwa IPS sebagai "the study of political, economic, culturals, and environment aspects of societies in the past, present and future"terdiri atas bahan pilihan yang sudah disederhanakan dan diorganisasikan secara psikologis dan ilmiah untuk tujuan pendidikan. (Sumantri 2001: 73)

Globalisasi ditandai 'lepasnya' jarak dan waktu sebagai konsekuensi kemajuan iptek. Batas-batas geografis menjadi samar-samar, nasionalisme telah memasuki fase baru. Dalam jaman pasca modern tersebut, menurut Giden, telah menghasilkan tiga lapisan politik, yakni etnik lokal, regional, jender atau ekologi; tingkat nasional; dan akhirnya tingkat supranasional, yang mencakup kawasan kontinental/komunitas global (Smith, 2003: 171). Dalam era ini isu-isu demokratisasi, HAM dan liberalisasi menjadi 
Social Studies (PIPS) Sebagai Upaya Meningkatkan Social Responsibility dan Social Skills Peserta Didik dI Tengah Globalisasi.

(Rahman Abidin)

realitas yang harus dihadapi dan direspon secara cerdas. Abad keterbukaan, dimana ideologi isolasionalisme akan tenggelam dan runtuh.

Melihat fenomena dan kecenderungan dunia yang terus maju bagaimana PIPS harus menempatkan diri (reposisi) dan Masih relevankah PIPS menjadi kekuatan pendidikan yang mampu menopang kehidupan umat manusia. Ada beberapa hal yang harus diperhatikan, apabila PIPS tetap ingin eksis dan mempunyai kedudukan yang berarti bagi umat manusia.

Penulis dapat menyimpulkan bahwa pendidikan IPS ditengah arus globalisasi harus mengimplementasikan pertama Pembangunan jati diri yang lebih tegas, integratif, dan tidak fragmentaris untuk mendapatkan kewibawaan, Kedua, Pembaharuan kurikulum PIPS hendaknya bukan sekedar tambal sulam, tetapi lebih bersifat interdisipliner, dan berorientasi pada 'functional knowledge" serta aspirasi kebudayaan Indonesia dan nilai-nilai agama, Ketiga Pengajar harus mampu menyajikan pengajaran/pembelajaran yang bersifat interdisipllin, berperan sebagai fasilitator pembelajar, dan menjadi problem solver baik di kampus/sekolah maupun di tengahtengah masyarakat, Keempat, membangun hubungan secara sinergis antara LPTK, praktisi pendidikan, sekolah, pembuat kebijakan pendidikan, serta berbagai elemen environment guna melakukan sharing untuk menyusun kurikulum yang integratif dan responsif terhadap permasalahan-permasalahan riil, baik lokal, regional, nasional maupun internasional, Kelima Kurikulum PIPS mampu membuat estimasi kehidupan yang akan berlangsung 30-50 tahun yang akan datang.

\section{Peran Social Studies Sebagai Upaya Meningkatkan Social Responcibility}

Ilmu Pengetahuan Sosial adalah mata pelajaran di sekolah yang di desain atas dasar fenomena, masalah dan realitas sosial dengan pendekatan interdisipliner yang melibatkan berbagai cabang ilmu-ilmu sosial dan humaniora seperti kewarganegaraan, sejarah, geografi, ekonomi, sosiologi, antropologi, pendidikan. Karena itu, IPS dapat dikatakan sebagai studi mengenai perpaduan antara ilmu-ilmu dalam rumpun ilmu-ilmu sosial dan juga humaniora untuk melahirkan pelakupelaku sosial yang dapat berpartisipasi dalam memecahkan masalah-masalah sosio kebangsaan. Bahan kajiannya menyangkut peristiwa, seperangkat fakta, konsep dan generalisasi yang berkait dengan isu-isu aktual, gejala dan masalah-masalah atau realitas sosial serta potensi daerah. 
Komponen penting yang harus dicapai oleh siswa dalam proses pembelajaran di sekolah. Untuk itu peran guru sangat diperlukan dalam pembentukan sikap sosial siswa selama di sekolah. Karena tanpa ada guru yang mendidik dan mengajar siswa di sekolah, sikap sosial siswa akan sulit untuk dibentuk dan dikembangkan. Inglis \& Aers (2008: 162) menyebutkan "responsibility is a concept and a value with multiple but intuitively well-understood meaning”. Maksudnya yaitu tanggung jawab merupakan sebuah konsep dan beberapa nilai akan tetapi maknanya sulit dipahami. Simorangkir (1987: 155) memberikan pengertian tanggung jawab sosial sebagai kemampuan manusia dalam kehidupan bermasyarakat dalam menjaga keseimbangan antara perilaku yang ditampilkan dengan harapan sesuai dengan status sosialnya (expectation). Guru yang membantu siswa untuk mengemban tanggung jawab sosial berarti guru telah memberikan kekuasaan terhadap siswa dalam pengambilan keputusan. Seperti yang dijelaskan oleh Hellison (2003: 13), “and helping students take personal and social responsibility means sharing power with students and gradually shifting decision making to them. TPSR does not mean getting inside kids' heads but getting them inside their own heads".

Pengembangan tanggung jawab sosial siswa bisa melalui kompetensi dan kepiawaian guru dalam mengelola kelas, membangun tim belajar dalam kelas dan menciptakan suasana pembelajaran bersama yang saling mendukung proses belajar (Koesoema, 2009: 159). Guru dapat memberikan kepercayaan kepada siswa yang memiliki kemampuan lebih untuk menjadi tutor bagi rekan sekelompoknya dalam mendiskusikan materi pelajaran. Melalui cara tersebut guru telah mengembangkan tanggung jawab sosial dalam diri siswa di lingkungan sekolah. Fakta di lapangan menunjukkan bahwa masih banyak guru yang lebih berorientasi pada penguasaan dan pemahaman anak terhadap materi pelajaran tanpa mempertimbangkan pembentukan karakter anak sebagai efek hasil belajar, sehingga materi pelajaran kurang bahkan tidak mewarnai sama sekali terhadap sikap dan kepribadian anak. Banyak guru yang menjadikan evaluasi sebagai tujuan, tidak menjadikan evaluasi sebagai alat untuk mencapai tujuan. Zuriah (2007: 39) bahwa keselarasan antara kata-kata dan tindakan dari guru akan sangat berarti dalam pembentukan karakter siswa. Jika guru mengajarkan pada siswanya untuk disiplin di kelas, akan tetapi guru tersebut sering terlambat masuk kelas, tentunya akan memberikan efek yang kurang baik terhadap penanaman sikap 
Social Studies (PIPS) Sebagai Upaya Meningkatkan Social Responsibility dan Social Skills Peserta Didik dI Tengah Globalisasi.

(Rahman Abidin)

sosial pada diri siswa. Oleh karena itu, guru yang ingin mengajarkan kedisiplinan pada siswa juga harus bersikap disiplin terlebih dahulu. Selain itu, sikap sosial siswa dapat terbentuk apabila guru sebagai pendidik memberikan contoh tindakan sikap sosial, tidak hanya memberikan teori saja.

Pengembangan tanggung jawab sosial siswa bisa melalui kompetensi dan kepiawaian guru dalam mengelola kelas, membangun tim belajar dalam kelas dan menciptakan suasana pembelajaran bersama yang saling mendukung proses belajar (Koesoema, 2009: 159) Seperti yang dijelaskan oleh Lickona (2013: 118) bahwa dalam mengajarkan pendidikan kakarter guru sebagai pendidik harus menggabungkan antara contoh yang baik dengan pengajaran langsung. Sehingga siswa mampu memahami dan meniru sikap sosial untuk diterapkan dalam dirinya.. Guru dapat memberikan kepercayaan kepada siswa yang memiliki kemampuan lebih untuk menjadi tutor bagi rekan sekelompoknya dalam mendiskusikan materi pelajaran. Melalui cara tersebut guru telah mengembangkan tanggung jawab sosial dalam diri siswa di lingkungan sekolah.

\section{Peran Social Studies Sebagai Upaya Meningkatkan Social Skills}

Menurut (Sjamsuddin dan Maryani, 2008:6), keterampilan sosial adalah suatu kemampuan secara cakap yang tampak dalam tindakan, mampu mencari, memilih dan mengelola informasi, mampu mempelajari hal-hal baru yang dapat memecahkan masalah sehari-hari, mampu memiliki keterampilan berkomunikasi baik lisan maupun tulisan, memahami, menghargai, dan mampu bekerjasama dengan orang lain yang majemuk, mampu mentransformasikan kemampuan akademik dan beradaptasi dengan perkembangan masyarakat global. Keterampilan sosial merupakan kemampuan untuk berinteraksi dengan orang lain dalam satu konteks sosial dengan suatu cara yang spesifik yang secara sosial dapat diterima atau dinilai dan menguntungkan orang lain.

Salah satu prinsip pembelajaran yang memiliki kekuatan yaitu berbasis nilai (value-based). Prinsip ini pula berlaku dalam pengembangan keterampilan sosial peserta didik dalam pembelajaran IPS. Keterampilan sosial banyak melibatkan aspek emosi dan perasaan yang merupakan ranah afektif. Dalam berinteraksi di masyarakat, segala sesuatu tidak akan pernah lepas dari nilai-nilai yang berlaku di masyarakat. Keterampilan sosial dan nilai merupakan dua hal yang tidak dapat dipisahkan dalam interaksi sosial di masyarakat. Oleh karena itu, sangat perlu pembelajaran IPS ynag berbasis nilai dalam rangka mengembangkan keterampilan sosila peserta didik. 
Pendidikan nilai dibagi kedalam dua pendekatan, yaitu pendekatan langsung dan pendekatan tidak langsung. Pendekatan langsung digunakan ketika melatih aspek-aspek yang berhubungan empati, seperti dengan cara contoh/modelling, sedangkan pendekatan tidak langsung digunakan ketika melatih keterampilan sosial berupa aspek kognitif sosial, seperti dengan cara diskusi.

\section{KESIMPULAN}

Tanggung jawab sosial dan keterampilan sosial peserta didik sangat tergantung pada guru sebagai pengembang kurikulum. Oleh karena itu, memahami misi kurikulum IPS, kemampuan transdisipliner, multiisiplin, cooperative study dalam memecahkan masalah sosial, harus dikuasai oleh setiap guru IPS, disamping kemampuan pengaplikasian metode, media, sumber belajar dan asesmen yang bervariasi. Pengembangan keterampilan sosial sangat tergantung pada guru sebagai pengembang kurikulum. Oleh karena itu, hal yang sangat penting diperhatikan dalam mengembangkan pembelajaran IPS yang bermuatan keterampilan sosial adalah sebagai berikut.

Guru sangat penting untuk membaca dan memahami isi kurikulum, khususnya kata-kata operational sebelum masuk kedalam substansi/isi kurikulum. Banyak guru yang terjebak kepada substansi materi sehingga materi IPS pun menjadi sarat dengan sejumlah materi yang harus dihapal; Guru, kepala sekolah dan tenaga kependidikan lainnya harus paham dengan misi tujuan pembelajaran IPS, jangan disamakan IPS dengan sisiplin ilmu sosial sehingga pembelajaran tidak subject oriented. Konsep tanggungjawab dan komitmen, perlu dipahami secara menyeluruh oleh semua unsur kependidikan, sehingga dalam menyelenggarakan pendidikan termasuk proses pembelajaran refleksi diri, perenungan akan makna isi, peristiwa, kejadian, pekerjaaan menjadi sangat penting untuk mengembangkan keterampilan sosial. Penguasaan dan pengaplikasian metode, media, asismen, dan sumberbelajar yang bervariasi untuk mendukung pengembangan keterampilan sosial peserta didik sesuai dengan psikologi perkembangannya; Ketercapaian hasil pembelajaran IPS jangan hanya dinilai oleh evaluasi yang sifatnya non tes saja pembelajaran yang sifatnya tematis.

Pendidikan IPS mengorganisasikan dan mengembangkan substansi ilmu-ilmu sosial secara ilmiah dan psikologis untuk tujuan pendidikan. PIPS mempunyai peran 
Social Studies (PIPS) Sebagai Upaya Meningkatkan Social Responsibility dan Social Skills Peserta Didik dI Tengah Globalisasi.

(Rahman Abidin)

penting dalam membangun identitas nasional untuk menjadikan siswa yang kreatif, mampu memecahkan masalah diri dan lingkungannya, serta menjadi warga negara yang baik dan bermoral. Di tengah iklim globalisasi, PIPS tetap diperlukan baik sebagai identitas nasional, maupun problem solver masalah-masalah lokal, regional, nasional, dan global. Berbagai masalah PIPS baik dari kurikulum, pengembangan di LPTK, kemampuan guru dalam mengajarkan, dan kebijakan pemerintah dalam mendorong PIPS yang ideal perlu terus diusahakan secara optimal. Tanpa sinergitas dari berbagai komponen di atas, sulit mewujudkan PIPS yang bermakna

\section{DAFTAR PUSTAKA}

Al-Muchtar, S. (2007). Strategi Pembelajaran Pendidikan IPS. Bandung: UPI.

Andriyanto, Muslikh. 2018. Nilai-Nilai Kejungan Sebagai Warisan Karakter Bangsa. Ombak : Yogyakarta.

Hellison, D. R. (2003). Teaching Personal and Social Responsibility Through Physical Activity. Third Edition. USA: Human Kinetics, Inc.

Inglis, F., \& Aers, L. (2008). Key Concepts in Education. Los Angeles: SAGE Publication.

Koesoema, D. (2009). Pendidikan Karakter di Zaman Keblinger. Jakarta: Grasindo.

Lickona, T. (2013). Mendidik Untuk Membentuk Karakter: Bagaimana Sekolah Dapat Memberikan Pendidikan Tentang Sikap Hormat dan Tanggung Jawab. (Terjemahan Juma Abdu Wamaungo). Jakarta: Bumi Aksara.

M. Numan Somantri, (2001), Menggagas Pembaharuan Pendidikan IPS, Rosda, Bandung.

Mahood, Wayne, et.al., (1991), Teaching Social Studies in Middle and Senior High Schools, Macmillan, Toronto.

Metiri Group (2009). Twenty First Century Skills (Online). Tersedia: http//www.metiri.com

Nursid, N. (2008). Konsep dasar IPS. Jakarta: Universitas Terbuka.

Sapriya. (2009). Pendidikan IPS Konsep dan Pembelajaran. Bandung: PT. Remaja Rosdakarya

Sardjiyo. (2007). Pendidikan IPS di SD. Jakarta: Universitas Terbuka. 
Simorangkir. (1987). Tanggung Jawab Manusia. Jakarta: Rineka Cipta.

Sjamsuddin dan Maryani E. 2008. Pengembangan Program Pembelajaran IPS untuk Meningkatkan Kompetensi Keterampilan Sosial. Makasar: Makalah pada Seminar Nasional.

Smith, A.D., (2003), Nasionalisme, Teori, Ideologi dan Sejarah, terj. Frans Kowa, Erlangga, Jakarta.

Syaodih, E. (2007). Pengembangan Model Pembelajaran Kooperatif untuk Meningkatkan Keterampilan Sosial (Online). Tersedia: http://educare.efkipunla.netindex2.php?option=c om_content\&do_pdf=1\&id=10 UNICEF. (2014). Laporan tahunan Indonesia 2014. Genewa: PBB. 